\title{
A Review on Tanduliyaka (Amaranthus spinosus L) - A Weed, A Vegetable and A Medicinal Plant
}

\author{
Review Article
}

\section{Karnam Chandrashekhar ${ }^{1^{*}}$}

1. Professor, Department of Dravyaguna, V.Y.D.S.Ayurveda Mahavidyalaya, Khurja, Uttar Pradesh, India 203131

\begin{abstract}
Weed is an unwanted plant growing on a cultivating land. Surprisingly, sometimes, certain weed turns out to be a great source of food or medicine. Nature has been so generous in providing a lot of useful things to humans. The great sages of Ayurveda have never let down any plant. They always tried to appreciate the usefulness of a plant in one or the other way. But, there are some instances where few therapeutic uses of certain plants were not documented in the literature of Ayurveda for unknown reasons. Ethno-botanical uses of such plants, if collected and studied, in addition to Ayurveda, will certainly make wonders in health care system. This review directs towards an underutilized, less explained, perhaps not significantly appreciated and categorically unspoken plant called Tanduliyaka (Amaranthus spinosus Linn) which has been used by many folklore and ethnic groups of India. This study reveals 45 synonyms of plant along with some notable ethno-botanical uses and its validated activities proving itself as the plant of much interest .
\end{abstract}

Keywords: Meghanada, Amaranthus spinosus L, Raktapitta, Migraine, Squalene.

\section{Introduction}

Many great medicines are perhaps, emerged from the information based on ethno botanical uses. Surprisingly, some drugs are brought to light as serendipitous occurrence. Occasionally, some drug candidates are developed from the plants which are used to treat various diseases mentioned in the traditional system of medicine, practiced in different countries of the world. Hence, the systemic study in to the facts mentioned in the traditional system and in ethno- botanical practices will provide a rationale for developing a novel drug. The information on the ethno botanical uses of a plant, sometimes, also involves the folklore claims and traditional uses. It appears that the ethnic individuals focused mainly on the plants available nearer to their habitats. The list of their drugs sometimes, includes the weeds as well.

Amaranthus spinosus L- commonly known as amaranth, is a weed found almost everywhere in India, has been a source of great interest these days. According to Monica et al. Amaranth has been touted as miracle grain, a super grain and the grain of future (1). Interestingly, Ayurveda has described a vegetable and a medicine in the name of Tanduliyaka which has been identified as Amaranthus spinosus L (2).

Taxonomic hierarchy (3)

Kingdom - Plantae

Sub kingdom - Viridiplantae

Infrakingdom - Streptophyta

*Corresponding Author:

Karnam Chandrashekhar

Professor, Department of Dravyaguna,

V.Y.D.S.Ayurveda Mahavidyalaya, Khurja,

Uttar Pradesh, India 203131

Email id: dkarnam@yahoo.com

$\begin{array}{ll}\text { Super division } & \text { - Embryophyta } \\ \text { Division } & \text { - Tracheophyta } \\ \text { Sub division } & \text { - Spermatophyta } \\ \text { Class } & \text { - Spermatophytina } \\ \text { Superorder } & \text { - Magnoliopsida } \\ \text { Order } & \text { - Caryophyllacae } \\ \text { Family } & \text { - Amaranthaceae } \\ \text { Genus } & \text { - Amranthus } \\ \text { Species } & - \text { spinosus L }\end{array}$

\section{Botanical description}

Figure 1: Photograph of Amaranthus spinosus L plant.

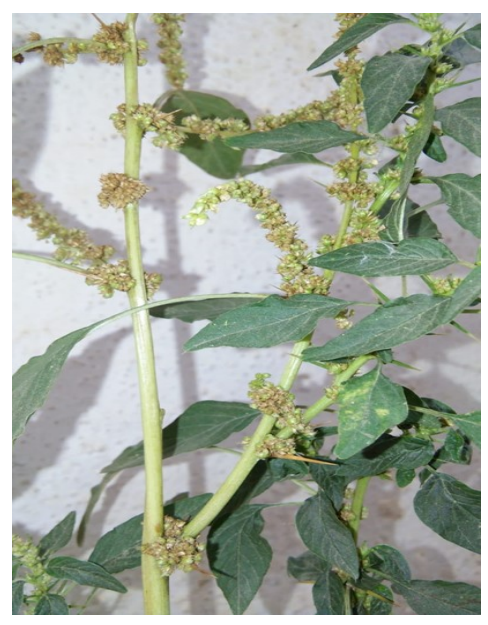

It is an erect glabrous herb $30-60 \mathrm{~cm}$ high; stems hard, often reddish, with many grooved branches and with sharp divaricate spined, often exceeding $1.3 \mathrm{~cm}$ long, in the leaf axils. Leaves $3.2-7.5$ by $1.3-3.8 \mathrm{~cm}$, ovate or lanceolate, obtuse, spinous-apiculate, entire, glabrous above, sometimes scurfy beneath; main nerves numerous, slender, conspicuous below; petioles 2-6.3 $\mathrm{cm}$ long, flowers very numerous, sessile, in dense 
axillary dense or interrupted spikes; bracteoles linear, bristle-pointed usually longer than the sepals. Perianth of male flowers $2.5-3 \mathrm{~mm}$ long; sepals 5, ovate, acute, bristle-pointed. Perianth of female flowers scarcely $1.5 \mathrm{~mm}$ long; sepals 5, oblong, obtuse, apiculate, stamens 5 , capsule $1.5 \mathrm{~mm}$, long, ovoid, thickened at the top, circumsessile, about the middle, membranous, rugose, styles 2, diverticate, pubescent (4). The plant is used in times of scarcity as pot herb. It is wholesome and agreeable. The plant is valued for its mucilaginous properties (5).

\section{Chemical constituents}

Analysis of the leaves and tender stalks gave moisture 84.5 ; fat 0.5 , protein 3.0 , carbohydrates 8.1 ; crude fibre 1.3 and ash $2.6 \%$, calcium 560.0, phosphorous 65.0, Iron30.5, Nicotinic acid 0.3; and ascorbic acid $30 \mathrm{mg} / 100 \mathrm{gm}$. The leafy vegetable is a very good source of calcium (Sen Gupta \& Pal, Jsci of Agric 1970, 21, 215; Devadatta \& Appanna, proc Indian acad sci $195439 \mathrm{~B}, 236)$. The leaves and stems contain $\alpha$ spinasterol and hentriacontane. The root contain $\alpha$ spinasterol, $\alpha$-spinasterol, octacosanoate $(\mathrm{C} 57 \mathrm{H} 102 \mathrm{O} 2$, m.p 85-860) and three saponins of $\alpha$-spinasterol (C47H88O16, m.p3400 and C47H88O16, m.p 2900) (Banerji, Indian J Chem, 1979, 17B, 180; Banerji, Indian chem soc 1980, 57, 417) (5).

The leaves contain large amount of oxalic acid, $116.4 \mathrm{mg} / 100 \mathrm{gm}$ (fresh wt. basis) Shingade, J Food Sci Technol.1995, 32, 429).The seeds contain a fatty oil, which is similar to corn oil. It contains a relatively high concentration (2.4-8\%) of squalene. The oil also contains a relatively high concentration of tocotrienols, a rare form of vitamin $\mathrm{E}$, which is reported to inhibit 3hydroxy-3-methylglutanyl coenzyme in cholesterol synthesis (Budin et al, J Am oil chem soc1996, 73, 475) (6). Amaranthus spinosus L contains 7- P cumaroyl apigenin 4-0-beta-D- glucopyranoside- a new coumaroyl flavone glycoside, hydoxy cinnamates, quercetin and kaempherol glycoside (Stintzing FC et al, 2004) betalins, betaxanthin, betacyanin, amaranthine and isomaranthine, gonphrenin, betanin, stigmasterol, linoleic acid $0.15 \%$ rutin and beta carotene (Blunden $\mathrm{G}$ et al 1999, Azham -ul -haq et al 2004) (7). This gives an idea that the plant has many useful constituents that can bring about a lot of biological changes in the body if administered in a proper dose and in proper form. Though the plant is a weed by nature, yet it bestows many healthy factors. Since, it contains many micronutrients and macro nutrients along with medicinal properties, its use in ethnic groups might be more. Keeping this fact in mind an earnest attempt is made in this review to find out multiple uses of Tanduliyaka (Amaranthus spinosus L) in Ayurveda and notable ethno botanical practices in different parts of India and their validation through the pharmacological studies.

\section{Aims and objectives}

To study the different uses of Tanduliyaka in Ayurveda literature giving much importance to the lexicons of Ayurveda.

To summarize the notable ethno botanical usage of Amaranthus spinosus L practiced by different tribes/ ethnics of India.

To study and summarize the notable pharmacological activity of Amaranthus spinosus L

\section{Materials}

- Classical texts such as Charaka samhita, Sushruta samhita and Astanga hridaya.

- Lexicons of Ayurveda.

- Research articles and Review articles.

- E- nighantus, E-articles

\section{Methods}

Information on Tanduliyaka is collected from the literature of Ayurveda giving much importance to lexicons of Ayurveda.

Ethno botanical usage of Amaranthus spinosus L collected from different review and research articles.

Pharmacological activities of Amaranthus spinosus $\mathrm{L}$ collected from different research articles.

Table 1: Synonyms of Tanduliyaka in different lexicons of Ayurveda

\begin{tabular}{|l|l|l|}
\hline \multicolumn{1}{|c|}{ Lexicon of Ayurveda } & \multicolumn{1}{|c|}{ Synonyms } & \multicolumn{1}{|c|}{ Ref } \\
\hline Amarakosha & Alpamarisha & 08 \\
\hline Astanga nighantu & Meghanada & 09 \\
\hline Siddha sara nighantu & Mahakala, Vega, Ghanasvana & 10 \\
\hline $\begin{array}{l}\text { Vyakhya on Dravyaguna } \\
\text { sangraha }\end{array}$ & Ksudra marisha & 12 \\
\hline Dhanvantari nighantu & $\begin{array}{l}\text { Uddistha, Tandula, Bhandira, Tandulibeeja } \\
\text { Meghanada, Ghanasvana }\end{array}$ & 13 \\
\hline Nighantu shesha & $\begin{array}{l}\text { Meghanada, Tanduli, Tanduleraka, Gandiraka, Raktakanda } \\
\text { anda, Vishahari, Alpa marisha Pathya, Tanduliyakah },\end{array}$ \\
\hline $\begin{array}{l}\text { Shodhala nighantu } \\
\text { (Nama sangraha) } \\
\text { Shodhala nighantu } \\
\text { (Guna sangraha) }\end{array}$ & \begin{tabular}{l} 
Samuddistha, Bhandira, Tanduli beeja, Meghanada, Vishapaha \\
\hline Abhidana ratnamala
\end{tabular} & 14 \\
\hline Madanapala nighantu & Ghanasvana Tanduliyaka, Vishghna, \\
\hline
\end{tabular}




\begin{tabular}{|l|l|l|}
\hline \multicolumn{1}{|c|}{ Lexicon of Ayurveda } & \multicolumn{1}{c|}{ Synonyms } & \multicolumn{1}{c|}{ Ref } \\
\hline Raja nighantu & $\begin{array}{l}\text { Bhandira, Tanduli, Tanduliyaka, Granthali, } \\
\text { Bahuveerya, Meghanada, Ghansvana, Sushaka, Pathyashaka, } \\
\text { Sphoorjathu, Svanitahvaya, Veera, ,andula, }\end{array}$ & 17 \\
\hline Kaiyyadeva nighantu & $\begin{array}{l}\text { Chandala, Chatala, Tanduliyaka, Kandeeram } \\
\text { Tanduli, Vega, Meghanada, Ghanasvana, Vishaghna, Kandara, } \\
\text { Beejipara, Varshika, Varshikau }\end{array}$ & 18 \\
\hline Vaidyamanorama & Megharava & 19 \\
\hline Vangasena & Tanduliyaka & 19 \\
\hline Bhavaprakasha nighantu & $\begin{array}{l}\text { Meghanada, Kandera, Tanduleraka, Bhandira, Tandulibeeja, } \\
\text { Vishaghna, Alpamarisha }\end{array}$ & 20 \\
\hline Saraswati nighantu & $\begin{array}{l}\text { Meghanada, Tandula, Tanduliyaka, Alpamarisha, } \\
\text { Meghanada, Tandula }\end{array}$ & 21 \\
\hline Shiva kosha & Meghanada & 22 \\
\hline Rasaratna samucchaya & Meghanada & 19 \\
\hline Laghu nighantu & $\begin{array}{l}\text { Meghanada, Tanduli, Tanduliya, Bhandiraka, } \\
\text { Raktapushpa, Vishahara, Alpamarisha }\end{array}$ & 23 \\
\hline Shaligrama nighantu & $\begin{array}{l}\text { Meghanada, Kandera, Tanduleraka, Bhandira, Tandoolibeeja, } \\
\text { Vishaghna, Alpamarisha }\end{array}$ & 24 \\
\hline Nighantu adarsha & Meghanada, Marisha & 19 \\
\hline
\end{tabular}

Table 2: Properties and actions of Tanduliyaka in different works of Ayurveda

\begin{tabular}{|c|c|c|c|}
\hline Texts & Properties & Actions & Ref \\
\hline Charaka samhita & $\begin{array}{l}\text { Rooksha, Madhura rasa, } \\
\text { Madhura vipaka, sheeta }\end{array}$ & Madaghna, Vishaghna, Raktapittahara & 25 \\
\hline Sushruta samhita & 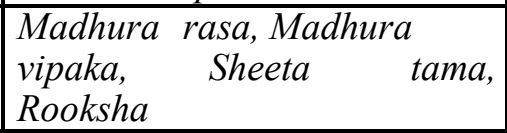 & Raktapittahara, madapaha, Visha hara & 26 \\
\hline Astanga hridaya & \begin{tabular}{|l|} 
Sheeta, \\
Rooksha, Madhura rasa, \\
Madhura vipaka, Laghu
\end{tabular} & Mada pittasraghna & 27 \\
\hline $\begin{array}{l}\text { Dhanvanatari } \\
\text { Nighantu }\end{array}$ & 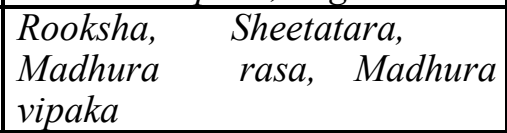 & Vishaghna, Raktapittapaghataka & 12 \\
\hline $\begin{array}{l}\text { Dravyaguna } \\
\text { Sangraha }\end{array}$ & Madhura vipaka & Asrukpitta vishanut & 28 \\
\hline $\begin{array}{l}\text { Madhava } \\
\text { Dravyaguna }\end{array}$ & Madhura vipaka & Asrukpitta vishanut & 29 \\
\hline $\begin{array}{l}\text { Madanapala } \\
\text { Nighantu }\end{array}$ & Laghu, Sheeta, Rooksha & $\begin{array}{l}\text { Pittakaphasrajit, Rochana, Deepana, } \\
\text { Srustha mala mutra, Raktapittahara }\end{array}$ & 16 \\
\hline Raja nighantu & Shishira, Madhura, & $\begin{array}{l}\text { Vishanashana, Ruchikrit, Deepana } \\
\text { Pathya, Pittadaha Brhamapaha }\end{array}$ & 17 \\
\hline $\begin{array}{l}\text { Kaiyyadeva } \\
\text { nighantu }\end{array}$ & $\begin{array}{l}\text { Sheeta, Rooksha, } \\
\text { Madhuara rasa, } \quad \text { Madhura } \\
\text { vipaka }\end{array}$ & $\begin{array}{l}\text { Madapittavishasraghna, Deepana, } \\
\text { Srushtamootravit }\end{array}$ & 18 \\
\hline $\begin{array}{l}\text { Bhavaprakasha } \\
\text { nighantu }\end{array}$ & Laghu, Sheeta, Rooksha, & $\begin{array}{l}\text { Pittakaphasrajit, Srustha mootra mala, } \\
\text { Rochana, Deepana, Visha haraka }\end{array}$ & 20 \\
\hline $\begin{array}{l}\text { Raja vallabha } \\
\text { nighantu }\end{array}$ & Madhura vipaka & Asrukpittavishanut & 30 \\
\hline $\begin{array}{l}\text { Shaligrama } \\
\text { nighantu }\end{array}$ & $\begin{array}{l}\text { Sheeta, Rooksha, } \\
\text { Madhura, }\end{array}$ & $\begin{array}{l}\text { Rochana, Deepana, Pathya, Daha } \\
\text { hara, Pittahara, Bhramahara, Visha } \\
\text { nashaka, Trushnahara }\end{array}$ & 24 \\
\hline Nighantu adarsha & $\begin{array}{l}\text { Madhura rasa, madhura } \\
\text { vipaka, sheeta veerya }\end{array}$ & Pittakaphahara & 19 \\
\hline Priya nighantu & Laghu, Sheeta, Rooksha, & $\begin{array}{l}\text { Pittakaphasrajit, Srushta mootra } \\
\text { mala, Rochana, Vishanashaka }\end{array}$ & 31 \\
\hline
\end{tabular}


Table 3: Notable ethno-botanical uses of Amaranthus spinosus $L$ in different parts of India

\begin{tabular}{|c|c|c|}
\hline State & Notable ethno- botanical uses & Ref \\
\hline Assam & $\begin{array}{l}\text { a) The plant juice is used in gastric trouble, burning sensation } \\
\text { during urination and antifertility } \\
\text { b) Root juice is given in diarrhoea. Taking as vegetable of tender shoot is } \\
\text { useful as galactogogue to nursing mothers }\end{array}$ & 32 \\
\hline Andhra Pradesh & Plant is used as laxative and also to treat tooth ache & 34 \\
\hline Arunachal Pradesh & The root paste is applied to the body against contagious skin infection & 35 \\
\hline Bihar & Root extract is given as a vermicide among the santhali and Paharia & 36 \\
\hline Chhattisgarh & \begin{tabular}{|l}
$\begin{array}{l}\text { Roots and leaves are used as laxative and to treat menorrhagia, } \\
\text { Gonorrhoea, night blindness }\end{array}$ \\
\end{tabular} & 37 \\
\hline Gujarat & $\begin{array}{l}\text { Stout old root juice mixed with equal quantity of milk is taken orally twice a } \\
\text { day for a week to cure painful urination. The root is used internally as a } \\
\text { diuretic, sudorific and febrifuge. The decoction is given for retention of urine }\end{array}$ & 38 \\
\hline Haryana & $\begin{array}{l}\text { a) The pills prepared from root paste of this plant are useful } \\
\text { to cure congestion of liver and irritation in urinary duct. } \\
\text { b) The decoction of root is also taken orally to cure stomach ache and applied } \\
\text { externally on wound and boil }\end{array}$ & 39 \\
\hline Himachal Pradesh & $\begin{array}{l}\text { a) Fresh juice of leaves acts as antidote in toxic conditions, intestinal } \\
\text { hemorrhages } \\
\text { b) Leaves and young shoots are cooked as vegetable by local people } \\
\text { c) Roots and leaves are used as expectorant }\end{array}$ & 40 \\
\hline Jammu and Kashmir & It is used for epistaxis, uterine bleeding piles and snake poison & 41 \\
\hline Jharkhand & $\begin{array}{l}\text { It is used in obesity (Ediriweere, 2007) eczema or abscess, dysuria } \\
\text { (satyapathy et al 2012)burns, wounds, inflammation, indigestion (Rajasab and } \\
\text { Isac 2004), laxative, emollient, spasmolytic, diuretic (Khare, 2007) }\end{array}$ & 42 \\
\hline Karnataka & $\begin{array}{l}\text { a) Leaf decoction is considered useful for improving } \\
\text { digestion. Leaves are applied as poultice to treat bruises, abscesses, burns, } \\
\text { wounds and inflammation } \\
\text { b) Leaves burnt and made in to ash, mixed with salt and applied on } \\
\text { affected teeth and gums to relieve tooth ache }\end{array}$ & 44 \\
\hline Kerala & $\begin{array}{l}\text { Decoction of roots is used daily for a period of } 2-3 \text { weeks for diuretic and anti- } \\
\text { lithiatic action }\end{array}$ & 45 \\
\hline Madhya Pradesh & $\begin{array}{l}\text { a) Extract of root is externally used for ripening of boils. Root is externally } \\
\text { used in eczema. } \\
\text { b) Boiled leaves and roots are given to children as laxative } \\
\text { c) Fresh roots are collected on Saturday are given to chew daily in the } \\
\text { morning for three days in spermatorrhoea }\end{array}$ & $\begin{array}{l}46 \\
47\end{array}$ \\
\hline Maharashtra & Root paste with coconut oil is applied during migraine & 48 \\
\hline Manipur & Whole plant is used to treat Leucorrhoea, Haemorrhoid and Gonorrhoea & 49 \\
\hline Mizoram & Shoots are eaten boiled & 50 \\
\hline Nagaland & $\begin{array}{l}\text { a)Plant is useful as blood purifier } \\
\text { b)Leaves and inflorescences are used to treat weak womb in women }\end{array}$ & $\begin{array}{l}51 \\
52\end{array}$ \\
\hline Odisha & $\begin{array}{l}\text { a) Root paste is applied around boils and carbuncle for easy } \\
\text { and speedy burst. Leaves are eaten as vegetables } \\
\text { b) Seeds of this plant and leaves of Datura_metel L are boiled in til-oil } \\
\text { (Sesamum indicum L) and applied to cure eczema }\end{array}$ & 53 \\
\hline Rajasthan & $\begin{array}{l}\text { a) Leaves, roots are used as laxative and abortifacient } \\
\text { b) It is used to treat excessive menstruation and vaginal discharges }\end{array}$ & $\begin{array}{l}55 \\
56 \\
\end{array}$ \\
\hline Sikkim & $\begin{array}{l}\text { Ethnic use of plant is mainly with the village people of Sikkim who use leaf } \\
\text { infusion in stomach disorder especially in case of indigestion and peptic ulcer }\end{array}$ & 57 \\
\hline Tamilnadu & Decoction of leaves is given to reduce the stomach pain & 58 \\
\hline Telangana & $\begin{array}{l}\text { Root is used to treat rheumatic pain and leaf is used as } \\
\text { Vegetable }\end{array}$ & 59 \\
\hline Tripura & $\begin{array}{l}1-2 \text { spoonful of fresh root infusion along with a pinch of } \\
\text { common salt is given orally in throat infection. Leaves and stems are used as } \\
\text { vegetable by tribals }\end{array}$ & 60 \\
\hline
\end{tabular}




\begin{tabular}{|l|l|l|}
\hline \multicolumn{1}{|c|}{ State } & \multicolumn{1}{c|}{ Notable ethno- botanical uses } & \multicolumn{1}{c|}{ Ref } \\
\hline Uttar Pradesh & $\begin{array}{l}\text { a) Grounded fresh roots can be applied on the snake bite area } \\
\text { b) Whole plant decoction is orally used to treat boils, burns, snake bite, skin } \\
\text { diseases and eruptive fevers. }\end{array}$ & 61 \\
\hline Uttara khand & Warm root paste, peach seed and salt are applied on unhealthy Ulcers & 62 \\
\hline West Bengal & Root decoction is used in indigestion and cure dysentery & 64 \\
\hline
\end{tabular}

Table-4: Notable pharmacological studies on Amaranthus spinosus L

\begin{tabular}{|c|c|c|}
\hline Activity & Study & Ref \\
\hline Antifertility potential & $\begin{array}{l}\text { The ethanolic extract of Amaranthus spinosus treatment caused } \\
\text { reduction in reproductive organ weights, number of implants (Gurumani et } \\
\text { al). }\end{array}$ & 65 \\
\hline Anti-depressant effect & $\begin{array}{l}\text { The anti-depressant effect of methanolic extract of Amaranthus } \\
\text { spinosus (MEAS) (100 and } 200 \mathrm{mg} / \mathrm{kg} \text { ) and Escitalopram and imipramine } \\
\text { were studied by observing the duration of immobility in two models:forced } \\
\text { swim test (FST) and Tail suppression test(TST) (Ashok kumar BS et al) }\end{array}$ & 66 \\
\hline $\begin{array}{l}\text { Anthelmintic activity and } \\
\text { anti-inflammatory } \\
\text { activity }\end{array}$ & $\begin{array}{l}\text { Aqueous extract of whole plant of Amaranthus spinosus showed } \\
\text { anthelmintic activity in a dose dependent manner. The study was } \\
\text { conducted on adult earthworm (Pheritima posthuma) and Tubifex tubifex } \\
\text { by using water extract of whole plant of whole plant of Amaranthus } \\
\text { spinosus and piperine citrate as reference standard. In anti-inflammatory } \\
\text { activity, ethanol extract showed much more potentiality than petroleum ether } \\
\text { extract when it was compared with standard drug Ibuprofen (Baral et al) }\end{array}$ & 67 \\
\hline Diuretic activity & $\begin{array}{l}\text { Aqueous extract of Amaranthus spinosus Linn (AEAS) produced } \\
\text { notable diuretic effect which appeared to be comparable to that by the } \\
\text { standard diuretic furosemide(Potllalli } \mathrm{S} \text { et al) }\end{array}$ & 68 \\
\hline $\begin{array}{l}\text { Anti-hyperglycaemic and } \\
\text { Anti-hyperlipidaemic } \\
\text { activity }\end{array}$ & $\begin{array}{l}\text { The methanol extract of Amaranthus spinosus stem was investigated for } \\
\text { its antihyperglycemic and antihyperlipidaemic effects in male wister albino } \\
\text { rats. The study was conducted by inducing diabetes in albino rats by } \\
\text { administering a single dose of alloxan monohydrate (150mg/kg i.p).The } \\
\text { methanol extract of A.spinosus (MEAS) was administered daily at single } \\
\text { doses of } 250 \mathrm{mg} \text { and } 500 \mathrm{mg} / \mathrm{kg} \text { p.o to diabetes induced rats for } 15 \text { days. } \\
\text { The result showed that A.spinosus has significant antihyperglycemic and } \\
\text { anti hyperlipidaemic effects (Sangameswaran Bala krishnan and Ramdas } \\
\text { Pandhare) }\end{array}$ & 69 \\
\hline $\begin{array}{l}\text { Anti- inflammatory effect } \\
\text { on cancer }\end{array}$ & $\begin{array}{l}\text { The methanol extract of Amaranthus spinosus leaves tested with different } \\
\text { doses for different cell lines. The result showed that the methanol leaf extracts } \\
\text { of Amaranthus spinosus leaves reveals significant anti- tumour effects in } \\
\text { cancers of breast, colorectal, liver and normal cell lines (Dinesh et al) }\end{array}$ & 70 \\
\hline Anti -ulcer activity & $\begin{array}{l}\text { Anti-ulcer activities of petroleum ether, chloroform, ethanolic extract of } \\
\text { Amaranthus spinosus leaf were tested for anti- gastric ulcer activity in shay } \\
\text { rat model. The anti-gastric activity of ethanolic extract of A.spinosus } 800 \mathrm{mg} / \\
\mathrm{kg} \text { body weight was found to be equal to the effect produced by } 2 \mathrm{mg} / \\
\mathrm{kg} \text { of Famotidine orally (Panda et al) }\end{array}$ & 71 \\
\hline Anti -microbial activity & $\begin{array}{l}\text { Maiyo et al, utilized different solvents like hexane, ethyl acetate, } \\
\text { dichloromethane and methanol leaf extracts of three plant species } \\
\text { Amaranthus hibridus, Amaranthus spinosus and Amaranthus caudatus for } \\
\text { anti- microbial activity. The leaves extract of plant species, extraction } \\
\text { fraction and various concentrations showed anti-microbial activity }\end{array}$ & 72 \\
\hline $\begin{array}{l}\text { Immuno } \\
\text { activity }\end{array}$ & $\begin{array}{l}\text { Lina et al investigated the immune-stimulatory effect of water extract of } \\
\text { Amaranthus spinosus in spleen cells from female mice. The results indicate } \\
\text { that the immune-stimulatory effects of ethanolic extract might be due to } \\
\text { stimulatory proliferation action on B lymphocyte activation and } \\
\text { subsequent T-cell proliferation in vitro. }\end{array}$ & 72 \\
\hline $\begin{array}{l}\text { Antigenic and Allergenic } \\
\text { activity }\end{array}$ & $\begin{array}{l}\text { Singh et al reported that Amaranthus spinosus five pollen samples act as } \\
\text { important aeroallergen in India and other different parts of the country. These } \\
\text { observations will be helpful in standardizing pollen antigens for diagnosis } \\
\text { and immunotherapy in India. }\end{array}$ & 72 \\
\hline
\end{tabular}




\section{Discussion}

Amaranthus spinosus L is known to the people of India from the time of Charaka in the name of Tanduliyaka. Its uses are documented in many of the lexicons of Ayurveda. Acharya Charaka considered it as a vegetable. This statement even holds true for acharya Sushruta, acharya Vagbhata and many others. Acharya Charaka advised it in treatment of raktapitta, sarva visha and pradara mainly. Sushruta considered it as a remedy for arsha, and mushika visha. Acharya Harita, in his work, advised it in the treatment of visha. While, Acharya Cahkapani datta recommended it in the treatment of atisara. Few unusual indication of Tanduliyaka are seen in Vangasena and Vaidya manorama. These two works indicated Tanduliyaka in Putinakha and Kookanaka respectively. A work on Rasa shastra known as Rasa ratna samucchaya recommended it in Karna pooya. This proves the fact that the plant is therapeutically used in various conditions. These therapeutic uses are documented with one of its names such as Meghanada or Megharava or Tanduliya or Tanduliyaka. During the period of lexicons, various synonyms have been coined to the plant. Amarakosha written during 4thcentury AD cited alpa marisha as the synonym of Tanduliyaka. Surprizingly, Saushruta nighantu written during 5th century AD, has not included the plant. But, Astanga nighantu (8th century AD) includes the plant with names Tanduliya and Meghanada. A total of 100 synonyms can be traced from lexicons written during different times. Of which 55 synonyms are repeatedly mentioned. The remaining 45 unrepeated synonyms are Tanduliya, Meghanada, Uddista, Tandula, Bhandira, Tandulibeeja, Ghansvana, Mahakala, Vega, Tandulee, Tanduleraka, Gandiraka, Raktakanda, Vishahari, Alpa marisha, Samuddista, Pathya, Tnaduliyakah, Vishapaha, Bhandiya, Mandiya, Ghnanamaka, Kandira, Vishaghna, Kavara, Marisha, Marshika, Granthili, Bahu veerya, Sushaka, Pathya shaka, Sphrujathu, Svaneetahvaya, Veera, Chandala, Chatala, Tandalee, Kandara, Beejipara, Varshika, Varshikau, Kandera, Bhandeeraka, Raktapushpa and Vishaha.

Almost all the authors considered its properties as madhura rasa, madhura vipaka, sheeta veerya laghu and ruksha guna.It pacifies kapha and pitta doshas. The laghu, ruksha and sheeta virya present in the plant mainly alleviate the drava, snigdha, teekshna and ushna guna of pitta and guru snigdha, picchila and slakshna guna of kapha.

On analysing its various actions, its dhatu gamitva can be described as rasa and rakta mainly. Since rasa and rakta provide shelter to kapha and pitta dosha respectively. It appears that it has a strong affinity towards rasavaha srotas, rakta vaha srotas, annavaha srotas, purisha vaha srotas and mutravaha srotas. It acts as mutrala and sramsana since it undergoes madhura vipaka. It eliminates the sroto dusti such as atipravritti and vimarga gamana.

Its list of indication can be made large by including the ethno-botanical uses practiced in different parts of the world. In India, various tribes or folks have tried this plant in various conditions other than the uses mentioned in Ayurveda. Many of the folk claims are validated with the help of pharmacological studies. But, still the plant demands some more studies with greater depth on other claims which are not subjected for pharmacological studies so far.

\section{Conclusion}

After analysing the literature on the plant Tanduliyaka (Amranthus spinosus L), it is found that the plant has some amazing medicinal properties that can be utilized in managing various conditions. Thus, the plant Tanduliyaka (Amaranthus spinosus L) proves itself as a medicine, a grain and a green. This review will help the researchers to contemplate on its folk claims and help in preparing new formulations.

\section{Acknowledgements}

I thank my wife Dr.Sampada M.K for the support during the study.

\section{References}

1. Amabye TG, Evaluation of physicochemical, phytochemical, antioxidant and Antimicrobial screening of Amaranthus spinosus leaves. Natural products chemistry and research. December 2015; 4 (1);1-5

2. Shastry JLN, Illustrated Madanapala nighantu. 1 ed, Varanasi;Chaukhambha orientalia; 2010.662p.

3. https: //www.itis.gov/servlet/singlerpt/

4. Kirtikar K.R, Basu B.D, Indian medicinal plants, 2 revised ed, Delhi; Periodical expert book agency; 2012.2057p.

5. Chadha YR, The wealth of India, New Delhi, National institute of science communication and information resources;2010; 1(A), 219p.

6. The Wealth of India, New Delhi, National institute of science communication and information resources; second supplement series, 1 (A-F), 51p

7. Asha S, Rekha R, Sadiq AM, Amaranthus spinosus- A review, Bulletin of environment, pharmacology and life sciences, August, 2016;vol 5 (9);102-107.

8. Pansikar VS, Amarakosha, reprint ed, Varanasi, Chaukhambha Sanskrit sansthan; 2014, 83p

9. Vahatacharya, Astanga nighantu (E.nighantu); Hyderabad, National institute of Indian medicinal heritage for CCRAS, 2012.

10. Ravigupta, Siddhasaranighantu (E.nighantu); Hyderabad, National institute of Indian medicinal heritage for CCRAS, 2012.

11. Shivadas sen, Vyakhya on Dravyaguna sangraha (E.nighantu); Hyderabad, National institute of Indian medicinal heritage for CCRAS, 2012.

12. Sharma PV, Sharma GP (2008) Dhanvantari nighantu, reprint ed. Varanasi, Chaukhambha orientalia, 2008, 140p.

13. Hemachandra suri, Nighantu shesha (E.nighantu); Hyderabad, National institute of Indian medicinal heritage for CCRAS, 2012.

14. Shodala, Shodala nighantu(E.nighantu); Hyderabad, National institute of Indian medicinal heritage for CCRAS, 2012.

15. Anonymous, Abhidana ratnamala(E.nighantu); 
Hyderabad, National institute of Indian medicinal heritage for CCRAS, 2012.

16. Madanapala, Madanapala nighantu (E.nighantu); Hyderabad, National institute of Indian medicinal heritage for CCRAS, 2012.

17. Tripathi ID, Rajanighantu of Pandit Narahari, Varanasi, Chaukhambha krishnadas academy, 2010, $119 \mathrm{p}$

18. Sharma PV, Kaiyyadeva nighantu, reprint ed, Varanasi, Chaukhambha orientalia, 2009, 115p

19. Vaidya BG, Nighantu adarsha, Varanasi Chaukhambha Bharati academy, Vol-2, 2013, 314$319 \mathrm{p}$.

20. Sitaram B, Bhavaprakasha of Bhavamishra, reprint ed. Varanasi, Chaukhambha orientalia, 2012, 446p

21. Anonymous, Saraswati nighantu (E.nighantu); Hyderabad, National institute of Indian medicinal heritage for CCRAS, 2012.

22. Shivadatta, Shiva kosha (E.nighantu); Hyderabad, National institute of Indian medicinal heritage for CCRAS, 2012.

23. Keshavarama, Laghu nighantu, (E.nighantu); Hyderabad, National institute of Indian medicinal heritage for CCRAS, 2012.

24. Vaishya LS, Shaligrama nighantu bhushanam, Mumbai, Shri venkateshwar press, 2011, 648-649p.

25. Pandeya GS, Charaka samhita of Agnivesha purvardha, reprint ed. Varanasi, Chaukhambha Sanskrit sansthan, 2007, 382p

26. Shastri AD, Sushruta samhita of maharshi sushruta, Varanasi, Chaukhambha Sanskrit sansthan, 2010, $264 p$

27. Upadhyaya Y, Astanga hridaya of Vagbhata, reprint ed. Varanasi, Chaukhambha prakashan, 2015, 103p

28. Chakrapani, Dravyaguna sangraha (E.nighantu); Hyderabad, National institute of Indian medicinal heritage for CCRAS, 2012.

29. Madhava, Dravyaguna sangraha (E.nighantu); Hyderabad, National institute of Indian medicinal heritage for CCRAS, 2012.

30. Rajavallabha, Rajavallabha nighantu, (E.nighantu); Hyderabad, National institute of Indian medicinal heritage for CCRAS, 2012.

31. Sharma PV, Priya nighantu, 2 ed, Varanasi, Chaukhambha surbharati prakashan, 1995, 112p

32. Buragohain J, Ethno medicinal plants used by the ethnic communities of Tin sukia district of Assam, India, Recent research in science and Technology, January 2011; 3(9):31-42

33. Kalita GJ, Rout S, Mishra RK, Sarma P, Traditionally used medicinal plants of Balaji subdivision, Barpeta, District Assam, Journal of medicinal plant studies, January 2015;3(2), 08-17

34. Divya K, Roja NM, Padal SB, Ethno medicinal plants used in east Godavari district, Andrapradesh, India, International journal of pharmacological research, 2015; 5(11), 293-300

35. Khansai M, Soikai SP, Kayang H, Ethnomedicinal plants used by different tribes of Arunachal Pradesh, Indian journal of Traditional knowledge, July 2011; 10(3), 541-546.

36. Hussain Z, Amaresh G, Singh S, Rao CV,
Antidiarrhoeal and anti-ulcer activity of Amaranthus spinosus in experimental animals, Journal of pharmaceutical biology, August 2009;47 (10)932-939

37. Singh RS, Shahi SK, Diversity of medicinal plants of Ratanpur region of Bilaspur district (Chattisgarh), Journal of medicinal studies, 2017; 5(2), 276-281

38. Punjani BL, Herbal folk medicines used for urinary complaints in tribal pockets of northeast Gujarat, Indian journal of traditional knowledge, January 2010; 9(1), 126-130

39. Yadav SS, Bhandoria MS, Ethno botanical exploration of Mahendragarh district of Harayana (India), Journal of medicinal plant research, May 2013;7(18) 1263-1271

40. Ramchand, Kaur R, Kaur A, Viney kumar, Nirmala C, Singh AN, Assessment of ethno medicinal plant diversity of Una and Harimpur district of Himachal Pradesh, India:An Ethno-ecological approach, Annals of plant sciences, December 2016; 5(12); 1475-1490

41. Srivastava TN, Rajashekharan S, Badola DP, Shah DC, An index of the available medicinal plants, used in Indian System of Medicine from Jammu and Kashmir state, July-September1986; 6(1), 49-63

42. Marandi RR, Britto J, Medicinal properties of edible weeds of crop fields and wild plants by oroan tribals of Latehar district, Jharkhand, International Journal of Life Science and Pharma Research. April 2015; 5(2), 9-20

43. Raja sab A.H, Isaq M, Documentation of folk knowledge on edible wild plants of north Karnataka, Indian journal of traditional knowledge, October 2004; 3(4)419-429

44. Parinita M, Harish GU, Vivek NC, Mahesh T, Shivanna MB, Ethno botanical wealth of Bhadra wild life sanctuary in Karnataka, Indian Journal of Traditional Knowledge, January 2004;3(1) 37-50.

45. Kumar SP, Lateef KA, Remashree AB, Ethno botanical survey of diuretic and antilithiatic medicinal plants used by traditional practices of Palakkad district, International journal of herbal medicine, July 2014; 2(2)52-56

46. Sahu SK, Weeds-as medicinal knowledge of Chitrakoot, Madhya Pradesh, International journal of multidisciplinary research and development, July 2015;2(7), 468-471

47. Shukla A, Srivastava S, Rawat AKS, an ethno botanical study of medicinal plants of Rewa district, Madhyapradesh, Indian Journal of Traditional Knowledge, January 2010; 9(1), 191202.

48. Kamble SY, Patil SR, Sawant PS, Sawant S, Pawar SG, Singh EA, Studies on plants used in traditional medicine by Bhilla tribe of Maharashtra, Indian Journal of Traditional Knowledge, July 2010;9 (3), 591-598.

49. Sanglakpam P Mathur RR and Pandey A, Ethno botany of Chote tribe of Bishnupur district (Manipur), Indian Journal of Natural Products and Resources, September 2012; 3(3), 414-425. 
50. Kar A, Bora D, Borthakur SK, Goswami NK, Saharia D, Wild edible plant resources used by the Mizos of Mizoram, India, Katmandu University Journal of Science, Engineering and Technology, July 2013, 9(1), 106-126.

51. Shankar R, Devalla RB, Conservation of folk healing practices and commercial medicinal plants with special reference to Nagaland, International journal of Biodiversity and Conservation, March 2012;4 (3) 155-163.

52. Imchen K, Jamir N.S (2011), Ethno medicinal plants used by the Phom-Naga tribe in longleng district of Nagaland, India, Pleione, May 2011; 5(1) 77-82.

53. Dash SS, Mishra MK, Tribal use of plants from Narayanapatna region of Koraput district, Orissa, Ancient science of life, Jan-Mar1996; 15(3), 230237.

54. Malik BK, Panda TB, Padhy RN, Traditional herbal practices by ethnic people of Kalanandi district of Odisha, India Asian Pacific Journal of Tropical Biomedicine, February 2012; 2(2)S988-S994.

55. Rana S, sharma DK, Paliwal PP, Sharma N, ethno medicinal exploration of some important plants of district Banswara(south Rajasthan)used by tribal community, International journal of bioassays, January 2004;3(2), 1729-1733.

56. Mathur M, Nama KS, Chaudhary K, Economic and ethno medicinal importance of the floral diversity on ancient walls of Kota district, Rajasthan, International Journal of Pure and Applied Bioscience, August 2016; 4(4), 167-173.

57. Rai PK, Shammy J, Gupta N, Rana R, An inside review of Amranathus spinosus Linn: A potential medicinal plant of India, International journal of research in pharmacy and chemistry, 2014, 4(3), 643-653.

58. Kadirvelurugan V, Raju K, Arumugam T, Karthk V, Ravikumar S, Ethno botany of medi-flora of kolli hills, Tamilnadu, Archives of applied science research, 2014, 6(1):159-164.

59. Saidulu P, Suthari S, Kandagatla, R, Ajmeera R, Vasavaya RS, Ethno botanical Knowledge studied in Pocharam wildlife sanctuary, Telangana, India, Notulae Scientia Biologicae, June 2015; 7(2)164170 .

60. Majumdar K, Datta BK, A study on ethno medicinal usage of plants among the folklore herbalists and tripuri medical practioners, part -2 , Natural product radiance, January-February 2007;6 (1), 66-73.

61. Gautam RP, Rajakumar SD, Srivastava SK, Singh S $\mathrm{K}$, Folk medicinal uses of plants from Kusmi forest, Uttarpradesh, Gorakhpur, India, International journal of current microbiology and applied sciences, November 2015; 4(7) 343-351.
62. Maurya SK, Seth A, Gautam DNS, Singh AK, Biodiversity and indigenous uses of medicinal plant in Chandra Prabha wild life sanctuary, Chandauli district, Uttar pradesh, international journal of biodiversity, February 2015, 1-11.

63. Uniyal B, Shiva V, Traditional knowledge on medicinal plants among rural women of the Garhwal, Himalaya, Uttaranchal, Indian Journal of Traditional Knowledge, July 2005; 4(3) 259-266.

64. Begum N, Mandal S, A contribution to the medicinal plants used by the tribal people of lateric belt of West bengal, World Journal of Pharmacy and Pharmaceutical science, July 2016; 5(8) 14201431.

65. Gurumani M, Balamurugan K, Evaluation of antifertility potential of ethanolic extract of whole plant of Amaranthus spinosus in female albino rats, World Journal of Pharmacy and Pharmaceutical Sciences, January 2014; 3(2), 2162-2167.

66. Ashok kumar BS, Lakshman K, Velmurugan C, Sridhar SM, Gopisetty S (2014) Anti- depressant activity of methanolic extract of Amaranthus spinosus L, Basic and Clinical Neuroscience winter 2014; 5(1) 11-17.

67. Baral M, Chakraborty S, Chakraborty P, Evaluation of anthelmintic and anti- inflammatory activity of Amaranthus spinosus Linn, International journal of current pharmaceutical research, July 2010; 2 (4) 44 $-47$.

68. Potlapalli S, Narumalla J, Naga Tejapavani A, Damodarum G, Chikkannnashetty SS, Study of diuretic activity of aqueous extract of Amaranthus spinosus Linn on rats, International Journal of Basic and Clinical Pharmacology, January 2017; 6(1)141-144.

69. Balakrishnan S, Pandhare R, Anti hyperglycemic and anti hyperlipidaemic activity of Amaranthus spinosus Linn extract on alloxan induced diabetic rats, Malasian journal of pharmaceutical sciences, 2010; 8(1), 13-22.

70. Rajasekharan S, Dinesh MG, Chandrasekharam K, Hussain F, Baig A(2014)Amaranthus spinosus leaf extracts and its anti-inflammatory effects on cancer, Indian Journal of Research in Pharmacy and Biotechnology, January -February2014;2(1)10581064.

71. Panda SK, Sarkar G, Manini A, Panda PK(2017) Anti-ulcer activity of Amaranthus spinosus leaf extracts and its comparison with famotidine in shay rats, Journal of Drug Delivery and Therapeutics, March 2017; 7(2) 96-98.

72. Asha S, Rekha R, Sadiq AM, Amaranthus spinosus- A review, Bulletin of Environment, Pharmacology and Life sciences, August 2016; 5(9) 102-107 